\title{
Serum copper and caeruloplasmin in ankylosing spondylitis, systemic sclerosis, and morphea
}

\author{
M. I. V. JAYSON,* P. DAVIS, ${ }^{*}$ J. T. WHICHER, $\dagger$ AND G. WALTERS $\dagger$ \\ From the Department of Medicine, University of Bristol and Royal National Hospital for Rheumatic Diseases, \\ Bath,* and Department of Chemical Pathology, Bristol Royal Infirmary $\dagger$
}

\begin{abstract}
Jayson, M. I. V., Davis, P., Whicher, J. T., and Walters, G. (1976). Annals of the Rheumatic Diseases, 35, 443-445. Serum copper and caeruloplasmin in ankylosing spondylitis, systemic sclerosis, and morphea. Studies of serum copper and caeruloplasmin were performed in patients with ankylosing spondylitis, systemic sclerosis, and morphea. Mean levels of both were raised significantly in ankylosing spondylitis, with the greatest increases in the worst cases. In patients with systemic sclerosis there was a significant increase in the mean level of caeruloplasmin, but not of copper, although both were raised in the 2 patients with the most aggressive disease. No alterations were found in patients with morphea. The values in the patients overlapped considerably with the values in the control subjects. It is thought that the increase in serum copper is probably secondary to the increase in caeruloplasmin which occurs as a nonspecific response to inflammation.
\end{abstract}

Abnormalities of serum copper and caeruloplasmin concentrations have been described frequently in rheumatoid arthritis. Although such changes also occur in nonrheumatological disorders, it is of interest that certain enzymes necessary for the synthesis of collagen are copper dependent. Therefore, we have studied the serum levels of copper and caeruloplasmin in patients with other diseases of connective tissue-ankylosing spondylitis, systemic sclerosis, and morphea.

\section{Materials and methods}

Blood was collected with plastic syringes into plastic containers and the serum stored at $-20^{\circ} \mathrm{C}$ until analysis. Serum copper was measured using a Perkin Elmer atomic absorption spectrophotometer (Model 103) and serum caeruloplasmin by immunodiffusion (Mancini, Carbonara, and Heremans, 1965) using commercial immunodiffusion plates (Behringwerke).

Measurements were made on 15 control subjects, 41 patients with ankylosing spondylitis, 22 with systemic sclerosis, and 6 with morphea. As there are no generally accepted criteria for grading the severity of ankylosing spondylitis, these patients were divided into three groups of mild, moderate, and severe, referring respectively to little or no restriction of spinal movement, marked restriction of spinal movement, and virtual rigidity of the spine.
Table I Sex distribution in controls and patient groups

\begin{tabular}{|c|c|c|c|}
\hline & Male & Female & Total \\
\hline $\begin{array}{l}\text { Controls } \\
\text { Ankylosing spondylitis } \\
\text { Systemic sclerosis } \\
\text { Morphea }\end{array}$ & $\begin{array}{r}3 \\
33 \\
3 \\
2\end{array}$ & $\begin{array}{r}12 \\
8 \\
19 \\
4\end{array}$ & $\begin{array}{r}15 \\
41 \\
22 \\
6\end{array}$ \\
\hline
\end{tabular}

\section{Results}

The sex distribution of the subjects is shown in Table I and the serum copper and caeruloplasmin levels in Figs. 1 and 2. In the spondylitic patients there was a significant rise in serum copper compared with the controls $(P<0 \cdot 01)$. In the systemic sclerosis group the mean copper was higher than in the controls but the difference was not statistically significant. In the morphea group the levels did not differ from the controls.

Caeruloplasmin levels were increased in both ankylosing spondylitis $(P<0.01)$ and systemic sclerosis patients $(P<0.05)$ but not in the morphea group. The highest caeruloplasmin levels were associated with the highest coppers (Fig. 3a, b, c). We examined the frequency of copper levels of 
$30 \mu \mathrm{mol} / 1$ or more and caeruloplasmin levels of $0.5 \mathrm{~g} / \mathrm{l}$ or more. There was a significant correlation of high levels of serum copper (Table II) and caeruloplasmin (Table III) with the severity of ankylosing spondylitis.

In three systemic sclerosis patients the serum copper was $>30 \mu \mathrm{mol} / \mathrm{l}$, the highest value found in the controls. Two of them had very extensive and rapidly progressing disease with gross visceral involvement, and within a few months both developed severe renal failure from which they died. The third patient, with the highest level of 65

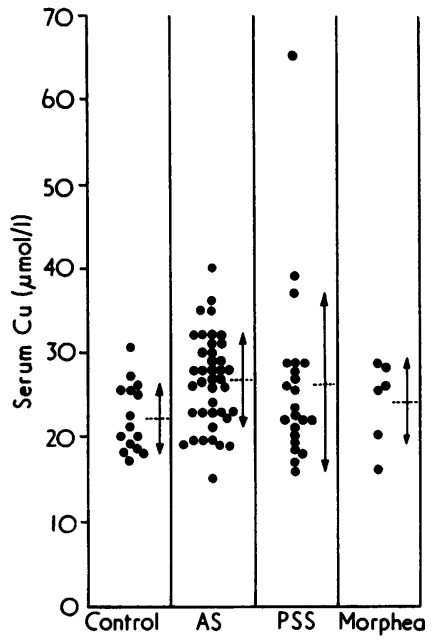

FIG. 1 Serum copper in controls, ankylosing spondylitis, progressive systemic sclerosis, and morphea. Conversion: SI to traditional units-Copper: $1 \mu \mathrm{mol} / \mathrm{l} \approx 6 \cdot \mathrm{J} \mu \mathrm{g} / 100 \mathrm{ml}$

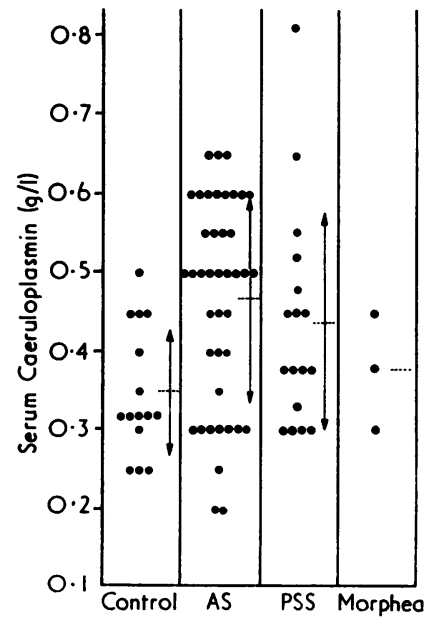

PIG. 2 Serum caeruloplasmin in controls, ankylosing spondylitis, progressive systemic sclerosis, and morphea
Table II Correlation of raised serum copper with severity of ankylosing spondylitis

\begin{tabular}{|c|c|c|c|}
\hline \multirow{2}{*}{$\begin{array}{l}\text { Copper } \\
\mu \mathrm{mol} / \mathrm{l}(\mu \mathrm{g} / 100 \mathrm{ml})\end{array}$} & \multicolumn{3}{|c|}{ Ankylosing spondylitis } \\
\hline & Mild & Moderate & Severe \\
\hline$<30(191)$ & $\overline{13}$ & $\overline{6}$ & 7 \\
\hline$>30(191)$ & 1 & 6 & 5 \\
\hline
\end{tabular}

Table III Correlation of raised serum caeruloplasmin with severity of ankylosing spondylitis

\begin{tabular}{|c|c|c|c|}
\hline \multirow{2}{*}{$\begin{array}{l}\text { Caeruloplasmin } \\
(\mathrm{g} / \mathrm{l})\end{array}$} & \multicolumn{3}{|c|}{ Ankylosing spondylitis } \\
\hline & Mild & Moderate & Severe \\
\hline$<0.5$ & 10 & 3 & 3 \\
\hline$>0.5$ & 4 & 10 & 8 \\
\hline
\end{tabular}

$\mu \mathrm{mol} / \mathrm{l}$, had comparatively mild disease but was taking the contraceptive pill. She was the only patient in the series receiving oestrogens.

\section{Discussion}

Both collagen, which is laid down in increased oे amounts in systemic sclerosis (Herbert and others 1974), and elastin are fibrous proteins which require the formation of intermolecular crosslinks for their stability. These crosslinks are formed by oxidative deamination of lysine residues catalysed by lysine and hydroxylysine oxidases which are copper dependent. Animals fed on copper-deficient diets develop skeletal abnormalities and defects in vascular elastic tissue (Carnes, 1971). However, it does not necessarily follow that high serum copper levels will result in or are necessary for increased formation of crosslinked collagen. In fact, our $\frac{0}{0}$ results suggest that raised serum copper is not of 3 . great importance in the pathogenesis of these $\delta$ diseases, as in almost all of the patients with systemic sclerosis and morphea the serum levels of copper 을 and caeruloplasmin were within the normal range. Even in the patients with ankylosing spondylitis, in whom raised levels were more frequent, there was still a very large overlap with the normal range.

A small amount of the plasma copper is bound to $N$ albumin which transports it to the liver after intestinal absorption. However, when released from the liver, copper is tightly bound to a specific protein caeruloplasmin, and most of the copper in plasma is bound to this protein. The level of serum $\stackrel{0}{\rightarrow}$ copper is therefore related to the level of caerulo- 0 plasmin so that in Wilson's disease, for example, a very low caeruloplasmin is accompanied by a very low copper level. Conversely, raised levels of $\frac{\mathbb{D}}{\mathbb{Q}}$ 


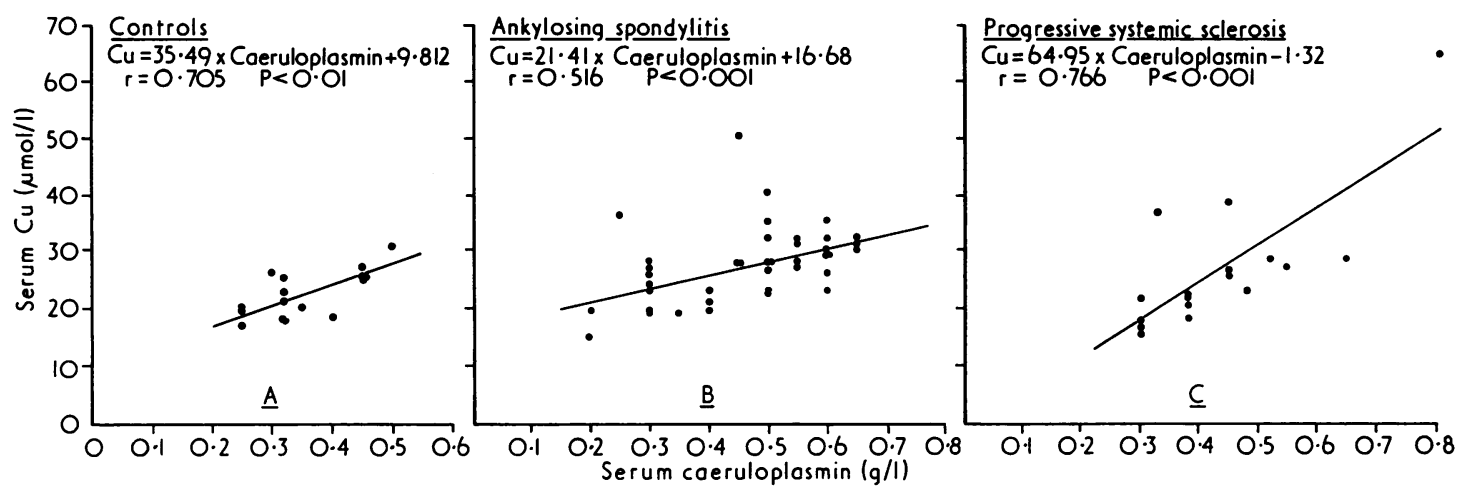

FIG. 3 (a) Correlation between serum copper and caeruloplasmin in controls; (b) ankylosing spondylitis; (c) progressive systemic sclerosis

copper in a wide variety of conditions (Scheinberg and Sternlieb, 1960) including pregnancy, oestrogen therapy, thyrotoxicosis, liver diseases, neurological diseases, Hodgkin's disease, carcinomatosis, and various conditions associated with inflammatory changes including rheumatoid arthritis (Niedermeier and Griggs, 1971; Hansson, Huunan-Seppälä and Mattila, 1975). Bajpayee (1975) attributed the high copper levels in rheumatoid arthritis to the patients being predominantly female and to some receiving oestrogens, as both these factors are associated with a rise in concentration of caeruloplasmin. This cannot be the explanation of our results as most of the spondylitics were male, but the controls were female so that sex selection alone would give lower values in ankylosing spondylitis. Moreover, we could correlate both copper and caeruloplasmin levels with disease severity.

Caeruloplasmin is one of the so-called acute phase reactants which increase nonspecifically in response to acute inflammation, and it seems very likely that in our patients raised serum copper was a secondary result of high levels of caeruloplasmin rather than a primary disturbance of copper metabolism. This seems to us also to be the likely explanation of the raised levels in rheumatoid arthritis, although increased urinary excretion of copper in the presence of a normal plasma level has been reported in this condition (McMurray and others, 1975).

The mechanism and purpose of the acute phase response are unknown, but it is interesting to note that copper may have an anti-inflammatory effect, so that raised levels might have some protective function. Maddox (1973) has shown that copper can inhibit production of the inflammatory prostaglandin $\mathrm{PGE}_{2}$ and perhaps stimulate production of the anti-inflammatory prostaglandin $\mathrm{PGF}_{2}$. Sorenson (1974) has also produced evidence that, when chelated by aspirin and other anti-inflammatory drugs, copper enhances their anti-inflammatory properties.

\section{References}

Bajpayee, D. P. (1975) Ann. rheum. Dis., 34, 162 (Significance of plasma copper and caeruloplasmin concentrations in rheumatoid arthritis)

Carnes, W. H. (1971) Fed. Proc., 30, 995 (Role of copper in connective tissue metabolism)

Hansson, L., HuUnan-Seppälä, A., And Mattila, A. (1975) Scand. J. Rheumatol., 4, 33 (The content of calcium, magnesium, copper, zinc, lead and chromium in the blood of patients with rheumatoid arthritis)

HerberT, C. M., LindBerg, K. A., JAYSON, M. I. V., AND Bailey, A. J. (1974) Lancet, 1, 187 (Biosynthesis and maturation of skin collagen in scleroderma and effect of D-penicillamine)

McMurray, W., Martin, V., Scudder, P., Stocks, J., White, A. G., and Dormandy, T. L. (1965) Ann. rheum. Dis., 34, 340 (Urinary copper excretion in rheumatoid arthritis)

MADDOX, I. S. (1973) Biochim. biophys. Acta, 306, 74 (The role of copper in prostaglandin synthesis)

Mancini, G., Carbonara, A. D., AND Heremans, J. F. (1965) Immunochemistry, 2, 235 (Immunochemical quantitation of antigens by single radial immunodiffusion)

Niedermeier, W., AND Griggs, J. H. (1971) J. chron. Dis., 23, 527 (Tracemetal composition of synovial fluid and blood serum of patients with rheumatoid arthritis)

Scheinberg, I. H., AND Sternlieb, I. (1960) Pharmacol. Rev., 12, 355 (Copper metabolism)

SORENSON, J. R. J. (1974) 'The anti-inflammatory activity of some copper chelates' in 'Trace Substances in Environmental Health-VIII', ed. D. D. Hemphill, p. 305. University of Missouri, Columbia 